Kamila M. Bezubik

Uniwersytet w Biatymstoku

Artur Olechno

Uniwersytet w Biatymstoku

\title{
CZY DEPOZYT WYBORCZY MOŻE STAĆ SIĘ CENZUSEM MAJĄTKOWYM? UWAGI NA PRZYKŁADZIE WYBORÓW GŁOWY PAŃSTWA
}

\section{Infamibus portae non pateant dignitatum?}

Depozyt wyborczy, rozumiany jako obowiązek wpłaty pewnej sumy pieniędzy konieczny do dokonania rejestracji kandydata w wyborach, co do zasady, nie jest traktowany jako cenzus wyborczy. ${ }^{1}$ Choć raczej nie ma wątpliwości, że właśnie z niego się wywodzi. ${ }^{2}$ Mimo że uważa się go za „formę bariery utrudniającej dostęp do procedur wyborczych części kandydatów", to jest akceptowany jako zabezpieczenie przed startowaniem w wyborach kandydatów „niepoważnych”, osób nieposiadających wystarczającego poparcia społecznego, a tym samym przed szkodliwym z punktu widzenia stabilności rządów fragmentaryzowaniem systemu partyjnego. ${ }^{3}$ Równie chętnie, jak w przypadku wyborów parlamentarnych, stosowany jest w wyborach prezydenckich. Tu argumentem go uzasadniającym jest np. weryfikacja politycznej doniosłości konkretnego zgłoszenia. ${ }^{4}$ Wysokość depozytu jest bardzo różna i najczęściej związana jest z rodzajem mandatu. Od najniższego i najrzadziej występującego w wyborach lokalnych, poprzez wybory parlamentarne do zwykle najwyższych stawek w przypadku wyborów głowy państwa.

Zdając sobie sprawę z obszerności tematyki depozytów wyborczych i w obowiązku sprostania ograniczeniom objętościowym, wybrane zagadnienie zostało przy-

1

Jak podnosi G. Kryszeń, mimo że reguły określające bierne prawo wyborcze powinny nawiązywać do standardów czynnego prawa wyborczego, to dopuszczalne jest występowanie pewnych dodatkowych ograniczeń, zawężających zasięg personalny biernego prawa wyborczego. Zob. G. Kryszeń, Standardy prawne wolnych wyborów parlamentarnych, Białystok 2007, s. 151.

2 A. Żukowski, Z problematyki depozytów wyborczych na świecie, „Studia BAS”, Nr 3(27), 2011, s. 32.

3 Zob. B. Michalak, „depozyt wyborczy”, (w:) B. Michalak, A. Sokala, P. Uziębło (red.), Leksykon prawa wyborczego i referendalnego oraz systemów wyborczych, Warszawa 2013, s. 38. Ibidem. 
bliżone w jednym tylko aspekcie. W niniejszym artykule autorzy chcieliby przyjrzeć się tematowi depozytów wyborczych na tle rozwiązań przyjętych w państwach europejskich w wyborach prezydenckich i odpowiedzieć na pytanie: czy nadmiernie zawyżona wysokość depozytu wyborczego nie powoduje, że instytucja ta (w zawoalowany sposób) powraca do swego, dziś uznawanego za niedemokratyczne, źródła? Mówiąc wprost, czy kaucja wyborcza wykazuje, a może raczej: czy może wykazywać cechy cenzusu majątkowego? Bliższe przyjrzenie się ordynacjom wyborczym $\mathrm{w}$ tej kwestii i porównanie ich do statusu życia obywatela danego państwa może spowodować, że z powyżej postawionych pytań usuniemy tryb przypuszczający. ${ }^{5}$

Powszechność wyborów można ująć jako prawo do głosowania i do kandydowania, które przysługuje wszystkim, którzy spełniają warunki określone w Konstytucji. Rzecz jasna, ustawy zwykłe mogą dookreślać wymagania dotyczące osób kandydujących, nie mogą jednak zanadto utrudniać udziału w wyborach osobom spełniającym kryteria konstytucyjne. Analizując zasadę powszechności wyborów można stwierdzić, że dopuszczalne jest wprowadzenie pewnych ograniczeń, co do kręgu podmiotów posiadających prawa wyborcze - w myśl łacińskiej paremii ,infamibus portae non pateant dignitatum". ${ }^{6}$ Przyjmując nawet, że kandydaci na określone wysokie funkcje państwowe muszą spełniać bardziej restrykcyjne wymogi niż inni wyborcy, należy pamiętać o tym, aby wprowadzane kryteria można było racjonalnie usprawiedliwić.

Właśnie jednym z takich ograniczeń jest instytucja kaucji wyborczych. Nie jest to mechanizm jednostkowy, występuje w ponad 80 państwach na świecie. Zwykle jest to wymóg występujący obok szeregu innych, niekiedy w praktyce trudniejszych do spełnienia, jak np. zebrania określonej liczby podpisów poparcia. ${ }^{7}$ Ostatnim elementem, potwierdzającym rejestrację kandydata, jest w tym wypadku właśnie wniesienie depozytu.

Jest to też mechanizm rekomendowany przez instytucje i organizacje międzynarodowe. Jak wspomniano, instytucja depozytu wyborczego, co do zasady, nie narusza kryteriów standardów demokratycznych wyborów. ${ }^{8}$ Europejska Komisja na rzecz Demokracji przez Prawo (Komisja Wenecka), jako organ doradczy Rady Europy, w celu zapewnienia demokratycznego i sprawnego funkcjonowania instytucji demokratycznych, a także ustawodawstwa wyborczego, dopuszcza wprowadzenie kaucji wyborczej. Kodeks dobrej praktyki w sprawach wyborczych z dnia 23

Równie interesująca wydaje się być analiza depozytów wyborczych w ordynacjach parlamentarnych, jednak ograniczenia objętościowe tekstu zmusiły autorów do zawężenia tematu i wyborów prezydenckich, jako przykładów najbardziej jaskrawych.

$6 \quad$ Przed niegodnymi niech nie stoją drzwi otwarte do sprawowania urzędów.

7 Jak zauważa A. Żukowski z reguły liczba ta jest znacznie niższa niż przy rejestracji kandydatów bez procedury depozytu wyborczego (waha się od kilku do kilkunastu głosów poparcia, a wyjątkowo do kilkudziesięciu czy kilkuset głosów poparcia). A. Żukowski, Z problematyki..., op.cit., s. 33. cały podnoszone zarzuty o jej niekonstytucyjności. Zob. szerzej M. Rulka, J. Zbieranek, Kaucje wyborcze jako mechanizm przejrzystości procesu wyborczego, Warszawa 2012, s. 9. 
maja 2003 r. ${ }^{9}$ odnosząc się do powszechności prawa wyborczego stanowi, że prawo to może, a nawet powinno być podporządkowane pewnym warunkom. W odniesieniu do depozytu wyborczego stwierdza, że powinien być on zwracany, jeżeli kandydat lub partia przekroczy pewien próg, a wysokość kaucji i wymagany próg nie powinny być nadmierne. Rozsądne wydaje się zatem przyjęcie, że akceptacja tej instytucji uprawniona jest wyłącznie wówczas, gdy wysokość kaucji ustalona jest na „niewygórowanym poziomie", ${ }^{10}$ co potwierdza również orzecznictwo Europejskiego Trybunału Praw Człowieka. ${ }^{11}$ A contrario ustalenie depozytu zbyt dużej wysokości będzie tych standardów naruszeniem.

Analogicznie należy spojrzeć na kwestię zwrotu wniesionej kwoty. Mamy wszak do czynienia z depozytem/kaucją, a nie opłatą wyborczą. Jeżeli kaucja ma służyć wyeliminowaniu „niepoważnych kandydatów”, to powinna być zwrócona tym, którzy otrzymali określone poparcie wyborców. ${ }^{12}$ Uzależnia się ją najczęściej od uzyskania odpowiedniej, procentowo ustalonej, liczby głosów. Naturalnie, jeżeli chcemy uniknąć zarzutu o cenzusie, ten próg również nie powinien być wygórowany. Ustalenie takiego rozsądnego pułapu jest szczególnie istotne w wyborach głowy państwa, gdzie zwycięzcą zostaje wyłącznie jeden ze startujących.

Porównajmy zatem modele depozytu przyjęte w wyborach prezydenckich w Austrii, Bułgarii, na Litwie oraz na Ukrainie.

\section{Pensio}

Ciekawym rozwiązaniem, uznawanym za funkcjonowanie kaucji wyborczej, ${ }^{13}$ jest przyjęty w Republice Austrii obowiązek ponoszenia przez kandydata na prezydenta kosztu druku kart do głosowania. Jest to kwota 3600 euro, ${ }^{14}$ przy czym nie jest ona zwracana, co pozwala zaliczyć ją do opłaty wyborczej (payment of a fee). Jednak biorąc pod uwagę jej wysokość oraz wysokość średniego (czy minimalnego) wynagrodzenia w Austrii, nie stanowi ona właściwie żadnego ograniczenia biernego prawa wyborczego. Intencją kaucji wyborczych jest wyselekcjonowanie takiej grupy kandydatów, którzy posiadając realne poparcie społeczne i poważne zamiary

Podstawowy dokument wypracowany przez Komisję Wenecką, przyjęty na 52. sesji w Wenecji (18-19.10.2002 r.), Kodeks dobrej praktyki w sprawach wyborczych z 23 maja 2003 r., Rada Europy CDL-AD (2002) 23 rev.

10 G. Kryszeń,Standardy..., op. cit., s. 171.

11 Według jednego z orzeczeń wysokość kaucji nie może dyskwalifikować kandydatów poważnych, ale znajdujących się w trudnej sytuacji ekonomicznej. Sukhovetskyy v. Ukraine-13716/02. Judgment 28.3.2006. http://hudoc. echr.coe.int/sites/eng/pages/search.aspx?i=002-3458\#\{,,itemid”:[,002-3458”]\} (data dostępu: 31.01.2015 r.). Zob. też np. Komentarz nr 16 do art. 25 Międzynarodowego Paktu Praw Obywatelskich i Politycznych Komitetu Praw Człowieka z dnia 19 grudnia 1966 r. (Dz.U. z 1977 r. nr 38 poz. 167) czy Decyzja nr 11406/05 Fournier v. France, 10.05.1988.

12 Por. International Standards and commitments on the Right to Democratic elections: A Practical Guide to Democratic Elections Best Practice, ss. 24 I 33. http://www.osce.org/odihr/elections/16859?download=true (data dostępu: 31.01.2015 r.).

13 A. Żukowski, Z problematyki..., op. cit., s. 39.

$14 \S 7$ ust. 9 Bundespräsidentenwahlgesetz 1971 - BPräsWG BGBI. Nr. 57 in der Fassung BGBI. I Nr. 115/2013. 
polityczne, nie zawahają się zaryzykować określonej kwoty pieniędzy. Znaczące jest w związku z tym optymalne określenie podstawowych składników kaucji: jej wysokości oraz zasad dotyczących zwrotu. Austriackie przepisy nie obarczają kandydata wielkim ryzykiem, usprawiedliwione (a przynajmniej niebudzące kontrowersji) w takim razie wydaje się być postanowienie o niezwracaniu poniesionych kosztów. Brak uiszczenia opłaty dyskwalifikuje jednak zgłoszenie kandydata. ${ }^{15}$

Wysokość kaucji ustalana jest różnie. Może to być określona suma pieniędzy lub wielokrotność minimalnego bądź przeciętnego wynagrodzenia. Taki sposób, dostosowany do sytuacji ekonomicznej obywateli, przyjęto w Republice Litewskiej. Kandydat na prezydenta zobowiązany jest przedstawić Centralnej Komisji Wyborczej Republiki Litewskiej dokument potwierdzający zapłatę kaucji w wysokości 5-krotności przeciętnego miesięcznego wynagrodzenia. ${ }^{16} \mathrm{~W}$ wyborach w $2014 \mathrm{r}$. wysokość kaucji wyniosła około 11500 litów, co nie wydaje się być sumą nadmiernie utrudniającą dostęp do startu w wyborach. ${ }^{17}$ Ponadto kaucja wyborcza jest zwracana osobie, która otrzymała więcej niż 7\% ważnie oddanych głosów, co wydaje się być również rozwiązaniem akceptowalnym. Choć oczywiście oznacza to, że część kandydatów zwrotu nie otrzyma. ${ }^{18}$

W Republice Bułgarii zmieniono wysokość kaucji wyborczej dla kandydata na prezydenta z 250 tys. lewa do 5 tys. lewa. ${ }^{19} \mathrm{~W}$ Bułgarii zwrot następuje na podstawie decyzji Centralnej Komisji Wyborczej, chyba że kandydat nie uzyskał 1\% ważnie oddanych głosów. ${ }^{20}$ Biorąc pod uwagę minimalną wysokość wynagrodzenia, wynoszącą na początku 2015 r. 360 lewa, mamy do czynienia z proporcją ok. 13-krotną. Stosunkowo małe ryzyko związane z oboma elementami depozytu (wysokością i zwrotem) miały oczywiście wpływ na liczbę startujących w wyborach. ${ }^{21}$

$\mathrm{Na}$ koniec dwa modele, których postanowienia, mimo zgodności z wymogami międzynarodowymi, budzą pewne wątpliwości ze względu na wysokość depozytu i warunki jego zwrotu.

Komisja Wenecka oceniając projekt kodeksu wyborczego Armenii uznała, że podjęta próba zwiększenia kaucji przy elekcji prezydenta z 5000-krotności

15 B. Naleziński, Prawo wyborcze na urząd prezydenta w Austrii, (w:) S. Grabowska, R. Grabowski (red.), Prawo wyborcze na urząd prezydenta w państwach europejskich, Warszawa 2007, s. 27.

16 Art. 36 ust. 2 Lietuvos Respublikos Prezidento Rinkimu İstatymas, Prezidento rinkimu j̇statymo 8, 11 ir 38 straipsniu pakeitimo įstatymo Nr. XI-2334 pakeitimai, ịsigalioję 2014-01-01, neitraukti i nuo 2013-11-23 naujai išdèstomo Lietuvos Respublikos Prezidento rinkimu įstatymo tekstą.

17 Jak podaje Litewski Departament Statystyki w 2013 r. średnie miesięczne wynagrodzenie wyniosło 2305 litów brutto, www.stat.gov.lt (data dostępu: 5.02 .2015 r.).

18 W wyborach prezydenckich w 2014 r. próg 7\% przekroczyło aż pięciu z siedmiu kandydatów, ale już w 2009 r. jedynie dwóch na zarejestrowanych siedmiu.

19 B. Pytlik, Różnice i modyfikacje w elekcji prezydenta w wybranych państwach Europy Środkowej, Wschodniej i Południowej, „Kwartalnik Kolegium Ekonomiczno-Społecznego. Studia i prace” 1(2012), s. 79.

20 P. Uziębło, Prawo wyborcze na urząd prezydenta w Bułgarii, (w:) Prawo wyborcze..., op. cit., s. 58.

21 Zmiany wysokości kaucji dokonano w 2001 r. W wyborach prezydenckich przeprowadzonych w 2001 r. wzięło udział sześciu kandydatów, 2006 r. siedmiu (w obu elekcjach wszyscy uzyskali powyżej 1\% głosów). W 2011 r. było ich już osiemnastu, z czego połowa przekroczyła 1\% próg wyborczy. Trudno jednak wyciągać z tego powodu zbyt daleko idące wnioski, ponieważ we wcześniejszych wyborach z lat 1992 i 1996 liczba kandydatów wynosiła odpowiednio: 22 i 13. 
na 8000-krotność minimalnego wynagrodzenia prowadziłaby do dyskryminacji potencjalnych kandydatów o niskim statusie ekonomicznym. ${ }^{22}$ Natomiast w opublikowanym w maju 2013 r. przez Organizację Bezpieczeństwa i Współpracy w Europie raporcie końcowym nt. przebiegu wyborów prezydenckich w Armenii przeprowadzonych w dniu 18 lutego 2013 r. autorzy nie mieli zastrzeżeń co do wysokości kaucji, która wyniosła 8 mln dramów armeńskich, tj. 14700 euro. ${ }^{23}$ Zakaz zwiększenia kaucji oznaczał jednocześnie uznanie, iż dotychczasowa jej wysokość spełnia wymogi stawiane demokratycznym wyborom. W 2013 r. minimalne wynagrodzenie w Armenii wynosiło 32 tys. dramów (w 2014 r. 50 tys., a obecnie 65 tys. dramów). Mieliśmy zatem w trakcie ostatnich wyborów prezydenckich wymóg wniesienia ok. 246-krotnego minimalnego wynagrodzenia (w 2015 r. byłaby to ok. 123-krotność). Inaczej mówiąc, była to kwota ok. 20-letnich zarobków minimalnych. Dysproporcja w porównaniu do wcześniej wspomnianych ordynacji jest ogromna. W efekcie na 15 kandydatów zgłoszonych przed dwoma laty jedynie 7 (a więc mniej niż połowa) było w stanie uiścić depozyt, a co za tym idzie dokonać ostatecznej rejestracji (w 2007 r. procedurę przeszło dziewięciu kandydatów).

Jak już wcześniej wspomniano, ważnym elementem kaucji jest także formuła jej zwrotu. Armenia ustaliła próg zwrotu kaucji na poziomie 5\% otrzymanych głosów. W praktyce oznaczało to, że w ostatnich wyborach zwrot depozytu otrzymało jedynie dwóch kandydatów. ${ }^{24}$

Ostatnim przywołanym państwem jest Ukraina, gdzie kilkakrotnie na przestrzeni ostatnich lat dochodziło do zmiany ordynacji prezydenckiej. W latach 1991, 1994 i 1999 kandydaci byli rejestrowani na podstawie zebranych podpisów poparcia wyborców. Początkowo było to nie mniej niż 100 tys. podpisów, w 1999 r. obowiązywał już wymóg przedłożenia 1 miliona podpisów. Kaucja wyborcza w wysokości 500 tys. hrywien została wprowadzona w wyborach z 2004 r., kiedy to nie zrezygnowano jeszcze z obowiązku zbierania podpisów, ale obniżono ich liczbę do wysokości 500 tys. Obowiązująca kaucja wyborcza w 2010 r. została podwyższona aż do 2,5 miliona ukraińskich hrywien. ${ }^{25}$ Uchylono wówczas obowiązek zbierania podpisów, co spowodowało, że właściwie jedynym wymogiem rejestracji kandydata stał się wspomniany depozyt. Co ciekawe, w wyniku tych nowelizacji liczba zgłaszanych kandydatów nie zmalała, a wzrosła. W 1991 r. było ich 6, w 1994 - 7, w 1999 r. - 15, w 2004 r. (wprowadzenie kaucji) - 26, w 2010 r. (podwyższenie kaucji) - 18, wreszcie w przedterminowych wyborach 2014 r. - 23. W ostatnich wyborach aż 11 kandydatów nie otrzymało nawet $1 \%$ poparcia, co stawia pod znakiem zapytania realizację

CDL-EL (2005)010, opinion no. 310/2004, European Commission for Democracy Through Law (Venice Commission), Draft Joint Oipinion on the Draft Amendments to the Electoral Code of Armenia, 19.04.2005.

Do 2008 r. depozyt wyborczy w wyborach prezydenta Armenii wynosił 5 milionów dramów.

W wyborach prezydenckich w 2008 r. czterech kandydatów uzyskało powyżej $5 \%$.

Art. 49 ust. 1 Ustawy Ukrainy „Pro wybory Prezidenta Ukrajiny”, „Widomosti Werchownoji Rady” 1999, Nr 14, s. 81. http://zakon1.rada.gov.ua/laws/show/474-14/print1299070987132750 (data dostępu: 11.02.2015 r.). 
celu - odrzucania kandydatów „niepoważnych”. Jak się okazuje, dużo skuteczniejszym rozwiązaniem był obowiązek zbierania podpisów.

Duża liczba kandydatów nie powinna przesłaniać jednak innych istotnych liczb. Minimalna płaca na Ukrainie na początku 2014 r. wynosiła 1218 hrywien miesięcznie, średnia zaś ok. 3700 hrywien. Oznacza to, że kaucja wyborcza była 675 razy wyższa w porównaniu do średniego wynagrodzenia i ok. 2050 (!) razy wyższa niż wynagrodzenie minimalne. W przeliczeniu na miesiące i lata depozyt wyborczy to kwota zarobków z 56 lat pracownika otrzymującego średnie miesięczne wynagrodzenie w kraju. Przeliczenie kaucji na wynagrodzenie minimalne jeszcze bardziej podkreśla jej absurdalność. To około 170 lat pracy osoby z minimalnym wynagrodzeniem. Oczywiście, w dużej mierze kaucja wyborcza nie jest pokrywana w całości przez jednego, startującego kandydata. Jej zebranie jest wynikiem pracy całego sztabu wyborczego i wysiłku finansowego osób popierających danego kandydata. Mimo powyższego zastrzeżenia jej wysokość nadal robi wrażenie, szczególnie kiedy porównamy ją z wymogami stawianymi w innych krajach. ${ }^{26}$

\section{Reddo}

Zastrzeżenia mogą budzić również zasady zwrotu depozytu wyborczego. W momencie wprowadzenia interesującej nas instytucji w 2004 r. zaczął obowiązywać przepis, według którego kaucja była przekazywana do budżetu państwa w przypadku nieuzyskania przez kandydata co najmniej 7\% głosów wyborców, którzy wzięli udział w głosowaniu. ${ }^{27}$ Już wówczas był to próg nieco wyśrubowany w porównaniu do rozwiązań obowiązujących w innych krajach. W latach 1991 i 1994 przekroczyło go jedynie 2 kandydatów. W 1999 r. zaś aż 5, co było chyba czynnikiem decydującym przy ustaleniu wysokości progu 7-procentowego po wprowadzeniu nowelizacji ustanawiającej 500-tysięczny depozyt. W 2004 r. ponownie jedynie dwóch kandydatów uzyskało powyżej 7\% i tym samym tylko oni otrzymali zwrot kaucji. Przy podwyższeniu wysokości depozytu ukraiński ustawodawca zmienił również zasady dotyczące jego zwrotu, które to rozwiązanie obowiązuje do dzisiaj. Kaucja wyborcza jest zwracana wyłącznie tym kandydatom, którzy zostali wybrani na urząd Prezydenta Ukrainy lub którzy wezmą udział w drugiej turze wyborów prezydenckich. ${ }^{28}$ Tym samym kaucja jest zwracana jednemu (w przypadku rozstrzygnięcia wyborów

Głosy krytyczne na Ukrainie nawet jeżeli się pojawiają, to pochodzą raczej ze strony organizacji pozarządowych czy publicystów niż przedstawicieli doktryny. Zob. np. S. Kononczuk, Hroszy dla kandydata w prezydenty, Ukrajinskij Nezależnyji Centr Politycznych Doslidżeń, http://www.ucipr.kiev.ua/publications/groshi-dlia-kandidata-v-prezidenti (data dostępu: 15.01.2015 r.) czy M. Naboka, Hroszowa zastawa dlja kandydatiw: wporjadkuwannja czy poruszennja praw?, http://www.radiosvoboda.org/content/article/26645601.html (data dostępu: 15.01.2015 r.).

27 P. Steciuk, K. Eckhardt, Prawo wyborcze na urząd prezydenta na Ukrainie, (w:) Prawo wyborcze..., op. cit., s. 199 .

28 Art. 49 ust. 2 Ustawy Ukrainy „Pro wybory...”, op. cit., http://zakon1.rada.gov.ua/laws/show/474-14/print12990709 87132750 (data dostępu: 11.02.2015 r.). 
w pierwszej turze) lub maksymalnie dwóm kandydatom (wobec braku uzyskania przez któregokolwiek kandydata bezwzględnej większości głosów), którzy w pierwszej turze uzyskali największą liczbę głosów.

Skoro uznaje się, że nie do przyjęcia jest uwarunkowanie zwrotu kaucji zdobyciem mandatu czy akceptacja reguły, w myśl której przepada ona zawsze, bez względu na wynik poparcia w wyborach, to na Ukrainie mamy do czynienia z przepisami niebezpiecznie zbliżającymi się do naruszenia standardów wolnych wyborów. ${ }^{29}$

Wobec przyjętych postanowień ordynacji wyborczej zasadne jest pytanie postawione w tytule tego artykułu. Czy depozyt wyborczy w zaproponowanej przez ukraińskiego ustawodawcę wersji nie nabiera cech cenzusu majątkowego? Dopuszczalne powinny być wszak ograniczenia mające jak najbardziej naturalny charakter, przy jednoczesnym wykluczeniu tych, które odbiegają od tej naturalności i wobec tego nabierają charakteru politycznego. ${ }^{30}$

Przywołane powyżej uwagi Komisji Weneckiej wydają się nazbyt łagodne i wydaje się, że mimo wszystko wręcz przyzwalające na nadmierne ograniczenia biernego prawa wyborczego. ${ }^{31} \mathrm{~W}$ naszym przekonaniu regulacje obu elementów kaucji wyborczej w Armenii, a szczególnie na Ukrainie mimo wszystko zawężają społeczeństwu tych państw możliwość wyrażania woli politycznej. Jak pokazują przykłady, nie chodzi nawet o zawężenie ilościowe (liczba kandydatów niekoniecznie maleje), ale polityczne, merytoryczne. Dochodzi do zmonopolizowania wskazanego uprawnienia przez określony typ podmiotów. ${ }^{32}$ Podmiotów, na tle ogółu społeczeństwa, wyróżniających się posiadanym majątkiem osobistym lub majątkiem członków własnego zaplecza politycznego. Podkreślmy, że nie chodzi wyłącznie o poszczególną treść przepisów ordynacji, ale o ich kontekst na tle sytuacji ekonomicznej kraju i zasobności finansowej obywateli.

\section{BIBLIOGRAFIA}

Galster J., Prawo wyborcze do Sejmu i senatu RP oraz status prawny posłów i senatorów (w:) Prawo konstytucyjne, Z. Witkowski (red.), Torun 2006

Grabowska S., Grabowski R. (red.), Prawo wyborcze na urząd prezydenta w państwach europejskich, Warszawa 2007

Kryszeń G., Prawo wyborcze do parlamentu. Status prawny posłów i senatorów (w:) Prawo konstytucyjne, S. Bożyk (red.), Białystok 2014

29 Por. G. Kryszeń, Standardy..., op. cit., s. 171.

30 Por. np. L. Garlicki, Polskie prawo konstytucyjne. Zarys Wykładu, Warszawa 2006, s. 152; G. Kryszeń, Prawo wyborcze do parlamentu. Status prawny posłów i senatorów, (w:) Prawo konstytucyjne, S. Bożyk (red.), Białystok 2014, s. 176 czy J. Galster, Prawo wyborcze do Sejmu i Senatu RP oraz status prawny posłów i senatorów, (w:) Prawo konstytucyjne, Z. Witkowski (red.), Toruń 2006, s. 2014.

31 Gdyby przekalkować dopuszczalną propozycję Komisji Weneckiej do średniego, miesięcznego wynagrodzenia kraju Europy Zachodniej, kaucja mogłaby wynieść np. 17 i pół miliona Euro (5000x3500 Euro - średnie wynagrodzenie w Niemczech w 2014 r.).

32 A. Żukowski, Systemy wyborcze, Olsztyn 1999, s. 42. 
Kryszeń G., Standardy prawne wolnych wyborów parlamentarnych, Białystok 2007

Michalak B., „,depozyt wyborczy”, (w:) B. Michalak, A. Sokala, P. Uziębło (red.) Leksykon prawa wyborczego i referendalnego oraz systemów wyborczych, Warszawa 2013

Garlicki L., Polskie prawo konstytucyjne. Zarys Wykładu, Warszawa 2006

Kononczuk S., Hroszy dla kandydata w prezydenty, Ukrajinskij Nezależnyji Centr Politycznych Doslidżeń, http://www.ucipr.kiev.ua/publications/groshi-dlia-kandidata-v-prezidenti

Naboka M., Hroszowa zastawa dlja kandydatiw: wporjadkuwannja czy poruszennja praw?, http:// www.radiosvoboda.org/content/article/26645601.html

Pytlik B., Różnice i modyfikacje w elekcji prezydenta w wybranych państwach Europy Środkowej, Wschodniej i Południowej, (w:) Kwartalnik Kolegium Ekonomiczno-Społecznego. Studia i prace $1(2012)$

Rulka M., Zbieranek J., Kaucje wyborcze jako mechanizm przejrzystości procesu wyborczego. Warszawa 2012

Żukowski A., Systemy wyborcze, Olsztyn 1999

Żukowski A., Z problematyki depozytów wyborczych na świecie, Studia BAS, Nr 3(27), 2011 


\section{COULD THE ELECTION DEPOSIT BECOME AN ELECTORAL QUALIFICATION? REMARKS ON THE EXAMPLE OF THE ELECTION OF HEAD OF STATE}

An election deposit, understood as an obligation to pay a sum of money necessary to register a candidate in the elections, is not usually treated as an electoral qualification. The deposit is levied as a hedge against "frivolous" candidates in the election process, who lack adequate public support. Equally often, as in the case of parliamentary elections, it is used in the presidential election. This way one guarantees political importance of a particular application. These deposits vary in rate, dependent (in most cases) on the type of mandate. From the smallest - in local elections, through the parliamentary elections (medium) to usually the highest rates in the presidential election.

Keywords: election deposit, electoral qualification, election

Słowa kluczowe: depozyt wyborczy, cenzus majątkowy, wybory 